\title{
The life of Leopoldo Fregoli
}

\author{
Graeme Yorston
}

The Fregoli delusion is one of a number of misidentification syndromes. It is characterised by a patient recognising a familiar person, usually seen as a persecutor, in various strangers who, although they do not show physical resemblance, are believed to be psychologically identical to the familiar person. It usually occurs in the context of a schizophrenic illness but has been reported in affective disorders and organic psychosyndromes (Förstl et al, 1991). It was first described by the French authors Courbon \& Fail in 1927, who used the term 'Fregoli illusion' after the Italian actor who enjoyed enormous popular success on the Paris stage at the time. It has also been called the 'illusion of negative doubles'. However, as the psychopathology is a delusional interpretation of normal visual stimuli rather than an abnormal perception the terms Fregoli delusion or 'delusional hyper-identification of the Fregoli type' are preferable. The original case description has recently been translated and annotated (Ellis et al 1994) but there remains little background information available on the figure of Fregoli himself. Biographies have appeared in French and Italian but there are few English language references and this paper is intended to provide an account of the life and career of one of the most extraordinary entertainers in theatre history.

In nearly 10000 performances over a 35 year period Leopoldo Fregoli thrilled his audiences of emperors, kings and commoners with his virtuoso music hall entertainments. From a stuttering start in his native Italy he advanced into Europe scoring critical and popular successes in Spain, Germany and Russia. He was acclaimed in New York and London and made several sell-out tours to South America but it was in Paris that his fame and popularity grew to mythic proportions: there, he was quite simply "Frégoli, roi" (Nohain \& Caradec, 1968).

Although born in a palace, his origins were humble. His mother was from a family of musicians and his father was the butler to
Count Pianciani in whose palace, close to the Trevi Fountain in Rome, Leopoldo was born in 1867. He was not a great success academically, preferring to spend his time throwing apples at passers-by, and he left school at 14 with no qualifications. He worked briefly as an apprentice clockmaker, railway mechanic and waiter but his dreams were of a life on the stage. He showed considerable talent for mimicry and parody from an early age and was an able singer in his local church choir. In his memoirs he tells how his uncanny ability to change his voice and transform his appearance was first appreciated by the cardinals and bishops attending parish shows (Fregoli, 1936).

His formal stage debut was at the age of 15 with an amateur company famous for having helped the early careers of several Italian actors. As well as straight roles in full length plays he tried his luck at conjuring tricks in magic shows which were often far from well received. Fortunately, he was young enough not to be put off by the boos and whistles. For another amateur company he performed his own adaptation of the finale of Donizetti's Il Campanello dello Speziale in which he sang all the male and female roles. This was his first real triumph and the format became the core of his act for the rest of his career.

However, he still had to persuade his father. This he managed by appearing on his doorstep dressed as a young woman. Falling into his father's arms, he tearfully demanded to know where his son was, the son who had seduced her and fathered her child, the faithless cad who was now disowning the infant. In the few seconds his father took to find smelling salts to restore the unfortunate swooning woman, Leopoldo was transformed back to himself. "Now do you believe I can be a comedian."

At 20 he began his military service in Bologna but having volunteered to serve in Eritrea he found himself in a small culturestarved colonial town. His commanding officer heard of his reputation and he was asked 

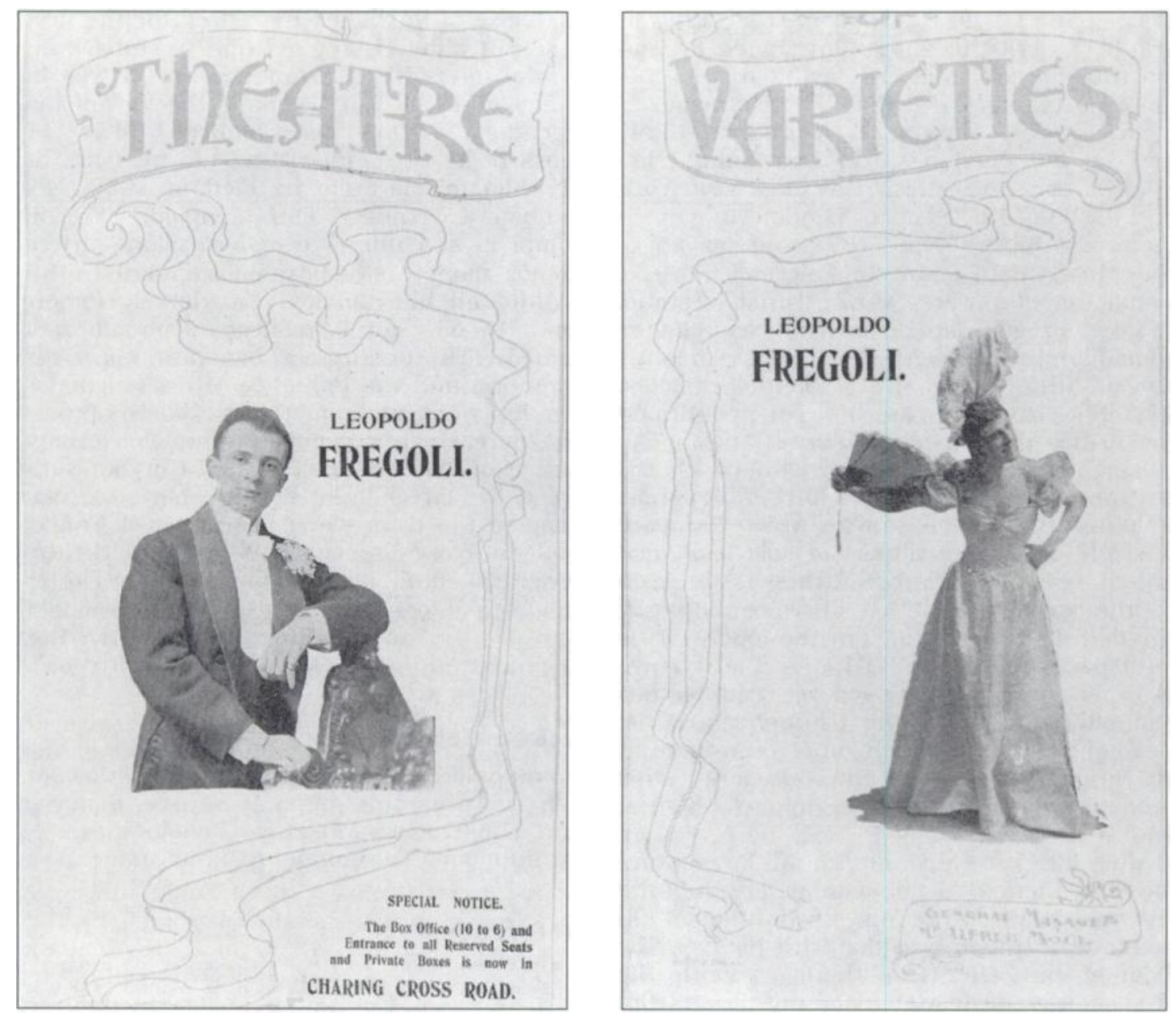

Photographs from Fregoll's 1897 Alhambra Theatre programme. Theatre Museum, V \& A.

to entertain the troops and civilians of Massawa. Obliged by the scarce means at his disposal, in particular the absence of any actresses, he adapted short plays and operas to be performed single-handed and with quick changes of costume. Age 23, and back in Rome, with his ideas and techniques still developing he made his professional debut. Chameleon and other shows proved extremely successful and he made enough money to form his own 'Compagnia di varieta internazionale' a rather seedy troupe with which he unsuccessfully toured Italy playing to halfempty houses. Undeterred and with a new impressario he formed another company to support his one man show, the 'Compagnia fin de secolo'. At last he had the formula right, the theatres filled and the money began to roll in.

A typical evening would start with a one act play, for example El dorado, in which a theatre director comes onto the stage explaining to the audience that he has been abandoned by his artists but that he intends to take their places and complete the advertised programme of song, dance, mime, ventriloquism, hypnosis etc. The second part of the performance would consist of comedy sketches, parodies and imitations of up to 60 theatre, political and literary figures (his London show included Gladstone, Sir Arthur Sullivan, Bismarck and Victor Hugo). The 
third part would consist of the 'Fregoligraph', a series of short films made by and starring Fregoli, and displaying further his amazing talents as a quick-change artist.

His success continued throughout Italy and he launched a world tour conquering Madrid, Buenos Aires, Havana, New York and Lisbon. He reached London in Queen Victoria's Jubilee year, 1897 and played at the Alhambra Theatre in Leicester Square. Initial reviews were warm if not ecstatic. "Signor Fregoli is the more accomplished comedian though perhaps the less finished singer (than his rival Biondi)" (Times, 11.3.97). However, as his run continued the critics grew in their appreciation: "Besides the extraordinary skill with which the costumes are changed in incredibly short time and the cleverness with which the more absurd conventionalities of old-fashioned Italian opera are parodied, his assumption of the various qualities of voice is really wonderful... as a skit on the opera it is faultless". (Times, 30.3.97). His final change of programme was received with the fervour characteristic of his later triumphs in Paris: "... a performance which must be unique in the annals of popular entertainment... this Protean entertainer... is a marvel" (Times, 24.4.97).

After London came Berlin, St Petersburg, Moscow, Vienna, all the capitals and half the crowned heads of Europe. In January 1900 he made his much heralded Paris debut at the Trianon but after less than a month the theatre was destroyed by a mysterious fire and his elaborate equipment along with it: $\mathbf{3 7 0}$ trunks of 800 costumes and 1200 wigs. This raised a massive wave of curiosity and sympathy and when he reopened at the Olympia only seven days later, he was a spectacular success selling out for the entire season of over 300 performances.

For the next 25 years his fame and popularity were sustained the world over. During the First World War he performed in many Red Cross gala evenings and, always a patriot, he chose to leave the big-time in order to entertain Italian troops in small military theatres close to the front lines. At the close of hostilities he retired for the first time but bankcruptcy led him to embark on a final tour of South America and it was in Brazil in 1925 that he made the last of his legendary 10000 performances. After 11 years of leisure and writing his memoirs at his villa in Viareggio he died in 1936. His tombstone reads: "Qui Leopoldo Fregoli compi la sua ultima transformazione" (Here Fregoli made his last transformation).

Although his name is now largely forgotten, Fregoli was a pioneer of music hall comedy. The one-man show was largely his invention and the influence of his cinematographic work in Lumière's studio is becoming increasingly recognised. Though we may find Courbon \& Fail's use of the verb 'frégolifier' (fregolify) a little obscure, we can imagine the days when the name of Fregoli was on every Frenchman's lips and theatre reviewers could write: "Italy has four glories of which it can be justly proud, the singer Caruso, the poet d'Annunzio, the inventor Marconi and the quick-change artist Fregoli".

\section{Acknowledfements}

I would like to thank Dr G. E. Berrios for help in obtaining original source material and The Theatre Museum, Tavistock Street, for supplying the Alhambra Programme.

\section{References}

Courbon P. \& FAll, G. (1927) Syndrome dillusion de Frégoll et schizophrenie. Bulletin de la Soctété Clinique de Médicine Mentale, 16. 121-125.

Euss, H. D.. WhImEY J. \& LuUTE. J. (1994) Delusional misidentification: The three original papers on the Capgras, Fregoli and intermetamorphosis delusions. Journal of History of Psychiatry. จ. 117-146.

FöRSTL. H., et al (1991) Psychiatric, neurological and medical aspects of misidentification syndromes: a review of 260 cases. Psychological Medicine, 21. 905-910.

Fregou. L. (1936) Fregoll Raccontato da Fregoli. Milan: Rizzoli.

Nohain, J. \& CARADEc. F. (1968) Frégoli-Sa Vie et ses Secrets. Paris: La Jeune Parque.

Graeme Yorston, Senior Registrar, The Elms Clinic, Oxford Road, Banbury, Oxon OX16 9AL 